\title{
Induced Membrane (Masquelet) Technique for Treatment of Long Bone Defects
}

\author{
AHMED M. LASHIN, M.Sc.; WEAM F. MOUSA, M.D.; MOHAMED M. HOSNI, M.D. and \\ EL-SAYED M.E. EL-FORSE, M.D.
}

The Department of Orthopaedic Surgery, Faculty of Medicine, Tanta University, Egypt

\begin{abstract}
Background: Reconstruction of large segmental bone defects following trauma, tumor resection or debridement of an infected segment, is a complicated problem with significant long-term morbidity, both for anatomical and functional results. Treatment of large bone defects represents a great challenge, as bone regeneration is required in large quantity and may be beyond the potential for self-healing. A two-stage technique uses induced biologic membranes with delayed placement of bone graft to manage this clinical challenge. In the first stage, a polymethyl methacrylate spacer is placed in the defect to produce a bioactive membrane. In the second, cancellous autograft is placed within this membrane and, via elution of several growth factors, the membrane appears to prevent graft resorption and promote revascularization and consolidation of new bone. Excellent clinical results have been reported, with successful reconstruction of segmental bone defects $>20 \mathrm{~cm}$.
\end{abstract}

Objective: The aim of the present study is to evaluate the Masquelet technique in the treatment of post-traumatic segmental bone defects.

Study Design and Setting: A prospective study.

Patients and Methods: This study included twenty patients having segmental bone defects ranging from 4 to $19 \mathrm{~cm}$ (average $6.35 \mathrm{~cm}$ ) either post-traumatic or following resection of the infected segment in cases of infected un-united fractures. All cases were treated using induced membrane (Masquelet) technique. The mean follow-up period was 11 months.

Results: Union was achieved in 17 patients (85\%). Satisfactory end results were achieved in fifteen patients $(75 \%)$ according to the system modified by El-Rosasy from Paley et al., Reconstruction failure with non-union occurred in three patients. Infective complications occurred in two patients $(10 \%)$. Both of them suffered from non-union.

Conclusion: The technique of delayed bone grafting after initial placement of a cement spacer provides a reasonable alternative for the challenging problem of significant bone loss in extremity reconstruction.

Key Words: Bone defects - Induced membrane-Masquelet.

Correspondence to: Dr. Ahmed M. Lashin,

The Department of Orthopaedic Surgery, Faculty of Medicine, Tanta University, Egypt

\section{Introduction}

TREATMENT of large segmental bone defects can be challenging for orthopaedic surgeons. Their prolonged, painful and uncertain treatment is usually beset with a range of consequences for the patient, varying from the psychological to the socioeconomic ones [1]. Trauma, bone tumors resections, osteomyelitis or treatment of congenital deformities are main etiologies of bone defects [2]

The critically-sized defect is described as segmental bone loss more than 2-2.5 times the diameter of the affected bone [3]. Smaller defects can be treated with autologous bone graft and rigid fixation [4]. When the defect size exceeds $4 \mathrm{~cm}$ a more specialized management is needed. Because beyond $4-5 \mathrm{~cm}$ defect, the bone graft gets resorbed and the defect remains [5-8]. The two well known techniques are the Ilizarov technique [1,9-13] and the vascularized fibular grafting [14-16]. Several other novel techniques have arisen over the years.

Vascularised fibular autografts have distinct benefits and allow simultaneous soft tissue coverage [17]. Nonetheless, problems are relatively common. These include infection and stress fracture, which can occur at both donor and recipient sites. The technique also requires specialist microsurgical expertise [17].

Although very popular and very successful worldwide as a method of bone regeneration, Ilizarov technique (bone transport and distraction osteogenesis) has several problems, specifically the long period of time that the external fixator needs to be kept on until the newly formed bone in the distracted zone consolidates $[\mathbf{1 0 , 1 8}]$. The development of contractures during distraction osteogenesis is a clinical complication that leads 
to functional deficits [19]. Other complications include pin site infections, pain and nonunion at the docking site [13]

Masquelet et al., in 1986 [5,20,21] described a procedure combining induced membranes and cancellous autografts. It is a two-staged technique. The first one entails debridement of the defect, stabilization of the limb and insertion of a polymethylmethacrylate (PMMA) cement spacer into the bony defect [22]. This spacer has a mechanical role in preventing the ingrowth of fibrous tissue and a biological role in that it provides an environment which will support the subsequent bone graft [22].

This occurs by inducing a foreign body reaction which results, four to six weeks later, in the formation of a pseudoperiosteum [22]. This membrane is vascularised and secretes key growth factors such as vascular endothelial growth factor (VEGF), transforming growth factor $\beta 1$ (TGF $\beta 1$ ) and bone morphogenetic protein-2 [23]. The second stage, which occurs six to eight weeks later, involves removal of the spacer while preserving the induced membrane [22]. The defect is filled with morcellized cancellous autologous bone graft. This, in turn, is protected from resorption by the pseudoperiosteum which encourages revascularization and corticalization [22-24]

\section{Patients and Methods}

This study included twenty patients having critically sized segmental bone defects ranging from 4 to $19 \mathrm{~cm}$ with a mean of $6.35 \mathrm{~cm}$. There were twelve $(60 \%)$ cases of acute traumatic bone loss (all were open fractures) and eight (40\%) cases of segmental defects following debridement in cases of infected un-united fractures. In addition two cases were excluded early in the study and did not proceed to second stage of the technique (one case due to persistence of infection in spite of multiple debridements and the other due to failure of soft tissue coverage technique, both cases were treated using Ilizarov technique). The age of the patients ranged from 8 years to 58 with a mean of $(28 \pm 11)$ years. Fourteen were males $(70 \%)$ and six were females $(30 \%)$. The tibia was affected in ten patients $(60 \%)$ while the femur in four $(20 \%)$ and the ulna in $6(30 \%)$ patients. All cases were treated by induced membrane (Masquelet) technique in orthopaedic department of Tanta University Hospitals in the period from September 2015 to September 2016. The period of follow-up ranged from 6 to 12 months (average 11 months).

\section{Methods of evaluation of the results:}

The results were assessed using the system modified by El-Rosasy from Paley et al., [10]. This included evaluation of bony union, residual deformity, residual leg length discrepancy, recurrent infection, soft-tissue healing, permanent joint contracture, persistent pain, return to previous work and patient satisfaction Table (1). The final results were considered to be satisfactory or unsatisfactory based on these findings.

Table (1): Evaluation of the results (El-Rosasy modification from Paley et al.).

\begin{tabular}{|c|c|c|}
\hline Parameter & Satisfactory & Unsatisfactory \\
\hline Bony union & United & Non-united \\
\hline Residual deformity & Less than $5^{\circ}$ & More than $5^{\circ}$ \\
\hline $\begin{array}{l}\text { Residual leg-length } \\
\text { discrepancy }\end{array}$ & Less than $2.5 \mathrm{~cm}$ & More than $2.5 \mathrm{~cm}$ \\
\hline Recurrent infection & No more infection & $\begin{array}{l}\text { Bone and/or } \\
\text { soft-tissueinfection }\end{array}$ \\
\hline Soft-tissue healing & No exposed bone & $\begin{array}{l}\text { Soft-tissue defect } \\
\text { remaining }\end{array}$ \\
\hline $\begin{array}{l}\text { Permanent joint } \\
\text { contracture }\end{array}$ & Less than $5^{\circ}$ & More than $5^{\circ}$ \\
\hline Persistent pain & No or mild pain & $\begin{array}{l}\text { Moderate or } \\
\text { incapacitating pain }\end{array}$ \\
\hline $\begin{array}{l}\text { Return to previous } \\
\text { work }\end{array}$ & Yes & Has to change job \\
\hline Patient satisfaction & Satisfied & Not satisfied \\
\hline
\end{tabular}

\section{Surgical technique:}

In the first stage of the technique, the area of bone loss was carefully debrided and irrigated, with removal of any gross debris and nonviable pieces of bone or soft tissue with a wide resection of all ischemic and necrotic tissue to a well perfused margin. Once acceptable reduction of the fracture is achieved (ensuring anatomic length, alignment, and rotation), fixation was undertaken. Ten cases were fixed by plate and screws constructs, four were fixed by interlocking nail devices, five were fixed by Ilizarov frames and only one case was fixed by intramedullary flexible nails. In infected or potentially infected cases, an external fixator was used as a temporary method of fixation changed later in the second stage to the definitive fixation by plate and screws or an intramedullary nail when there is no evidence of infection. Once fixation has been achieved, the defect was measured and filled with a polymethyl-methacrylate (PMMA) cement spacer. It was mixed with vancomycin in a ratio of $8 \mathrm{~g}$ to each $40 \mathrm{~g}$ of the spacer. The spacer was then inserted as a block during later stages of polymerization to allow proper sizing and shaping of the spacer. It is important to fill the whole defect with the spacer, from bone end to bone end. The wound was then closed carfully in a layered fashion with a watertight facial closure. In the presence of soft tissue defect, repair or reconstruction were performed (Fig. 1). 


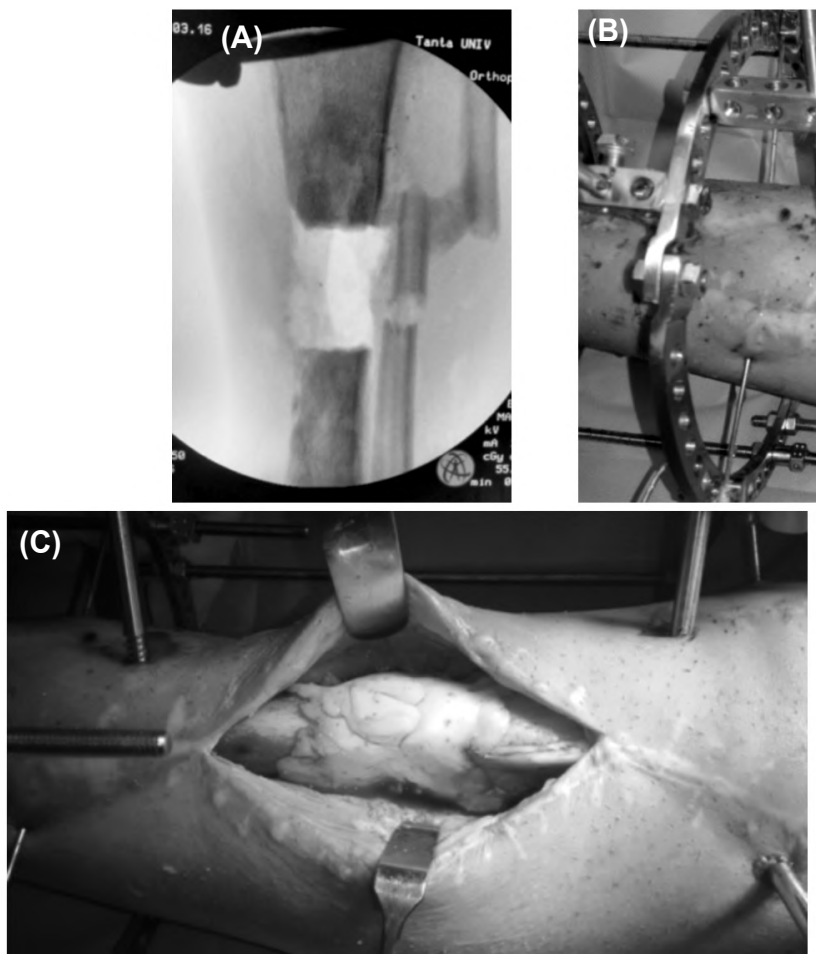

Fig. (1): A: Intra-operative fluoroscopy after resection of the necrotic segment. B: Debridment. An Intraoperative image following debridement and resection of necrotic and infected segment. C: Insertion of the spacer. as a block overlapping the bone end.

The second stage procedure was performed 4 to 8 weeks after the first if soft tissue permits and only if there was no clinical or biochemical evidence of ongoing infection as indicated by normal white blood cell count, C-reactive protein and erythrocyte sedimentation rate.

The fracture was approached through the previous incision and careful dissection until the bio-active membrane is identified and then it is incised carefully. The cement spacer was then removed en bloc or in a piecemeal fashion. An osteotome can be used to split the cement spacer longitudinally into smaller pieces before removal. It was critical to be sure to remove all of the cement and not to violate the membrane at any point (Fig. 2). Cortical bone ends was freshened with osteotomes or curets to improve graft incorporation to native bone. Bone graft (with or without bone graft substitute according to the size of the defect) was then placed to fill the entire defect. (Fig. 3) the biomembrane was closed with absorbable Vicryl suture followed by wound closure in a layered fashion.
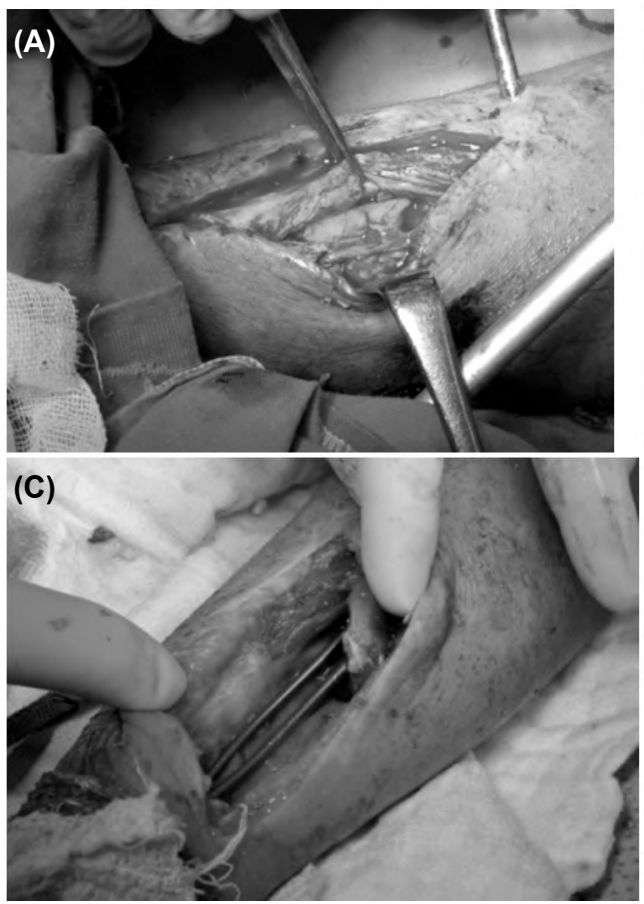
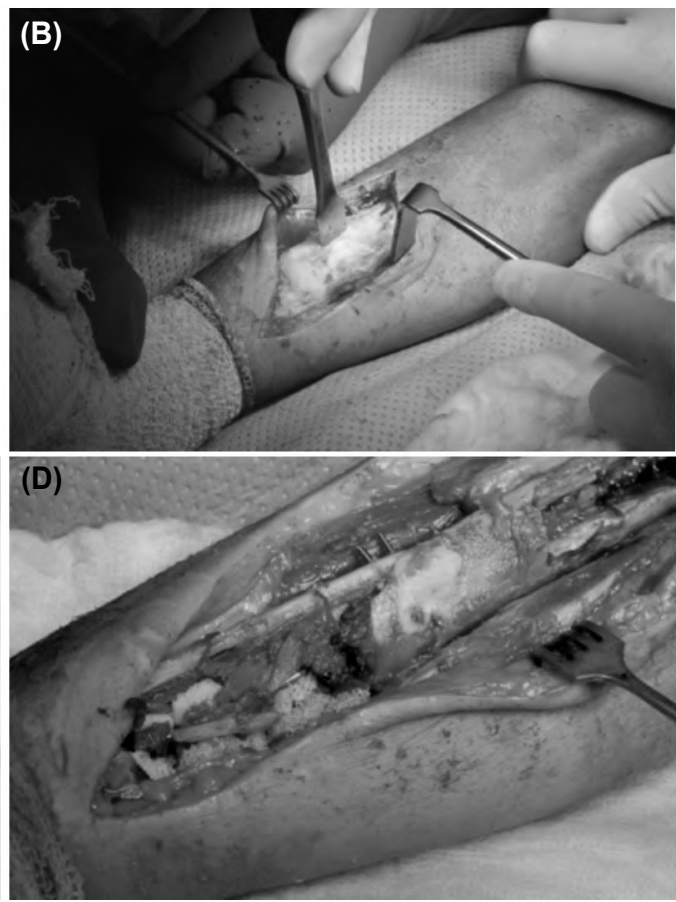

Fig. (2): A: Exposure of the spacer. The membrane is carfully incised to allow removal of the spacer. B: Splitting the spacer. An osteotome can be used to longitudinally split the cement spacer into smaller pieces before removal. C: After spacer removal and saline irrigation. D: Graft insertion. Intraoperative image after graft insertion with the use of cancellous allograft in addition to the autograft to fill the void. 

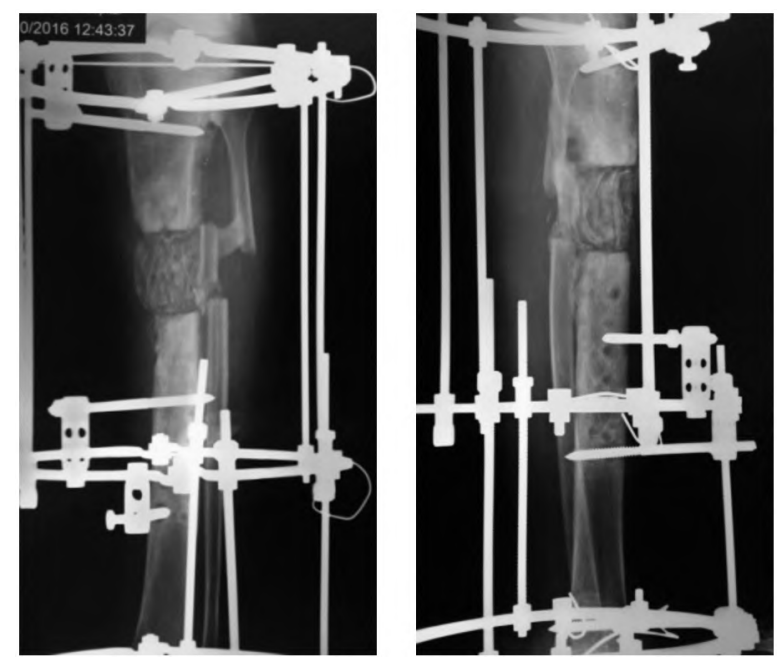

Fig. (3): Post-operative radiographs following graft insertion.

\section{Results}

Union was achieved in 17 patients (85\%). (Fig. 4) Nonunion occurred in three patients $(15 \%)$. The
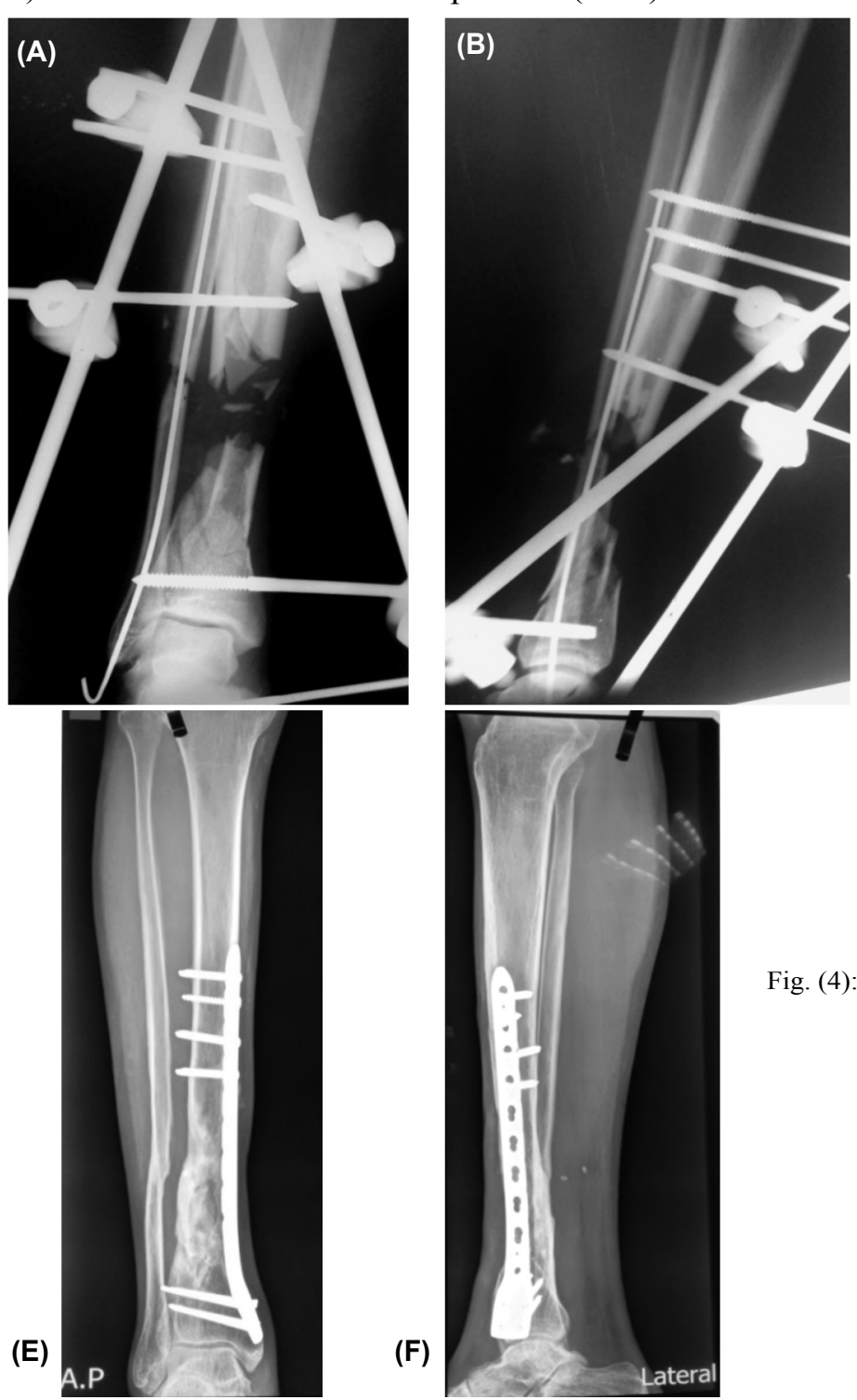

(F)

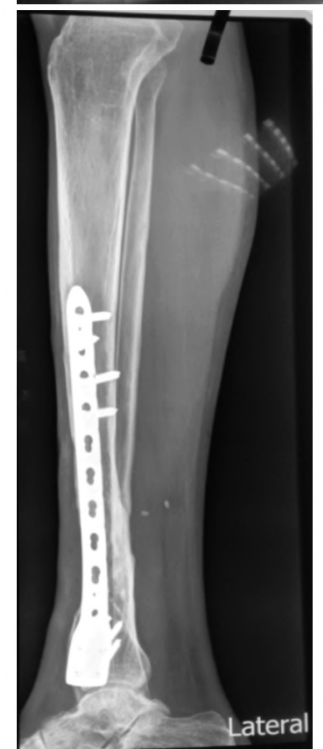

duration to union from the date of the second stage ranged from 2.5 to 8.5 months (a mean of 4.5 months) in both upper and lower extremity segmental defects. Significant deformity occurred in only one patient $(5 \%)$ with residual deformity of the tibia more than 5 degrees, was treated by Ilizarov to correct the deformity. Significant shortening more than $2.5 \mathrm{~cm}$ occurred in one patient. The same patient suffered from non-union and recurrent infection. This case was managed by a free vascularized fibular graft. Infective complications occurred in two patients $(10 \%)$. Both of them suffered from non-union. One patient suffered from elbow stiffness due to presence of ipsilateral intercondylar fracture humerus. Another patient suffered from knee stiffness. As regard the final end results, satisfactory end results were achieved in fifteen patients $(75 \%)$, while unsatisfactory results occurred in five patients (15\%) according to the system modified by El-Rosasy from Paley et al., [10] .
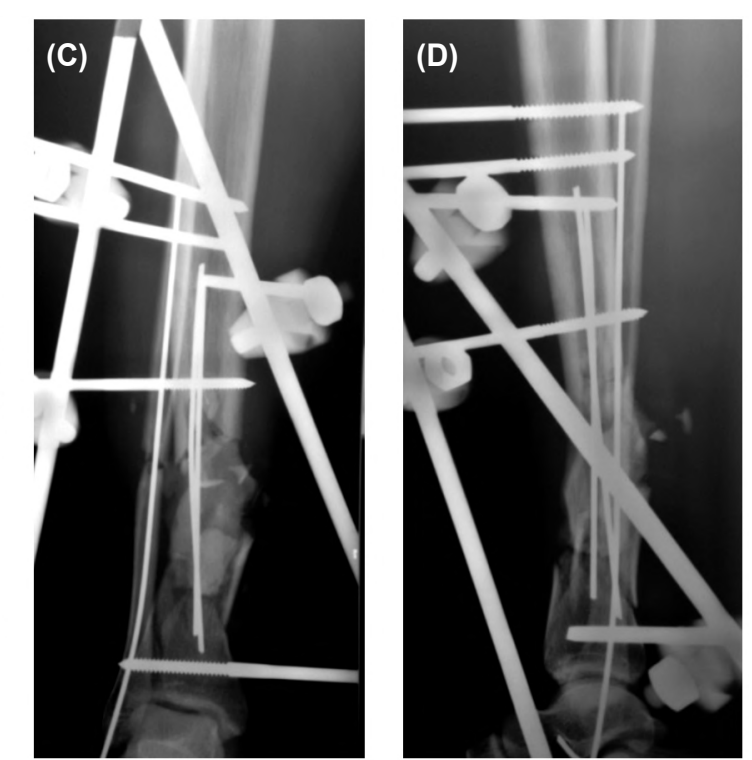

Fig. (4): A and B: Post-operative X-rays of an open fracture (Gustillo IIIa) both bones leg with segmental bone loss about $7 \mathrm{~cm}$ after debridement and primary fixation. $\mathrm{C}$ and D: Post-operative $\mathrm{X}$ rays following the first stage after spacer application. $\mathrm{E}$ and $\mathrm{F}$ : Final follow-up radiographs of the same case with complete union. 


\section{Discussion}

Reconstruction of extensive segmental bone loss is still a major therapeutic challenge, both for anatomical and functional results. The limits of conventional bone graft are clear, mainly for uncontrollable graft resorption. Among the most recent techniques, vascularized fibular graft and bone transport distraction osteogenesis by Ilizarov have provoked the most interest as reliable options for managing such difficult cases. However, In 1986 Masquelet proposed a novel technique based on the concept of induced membrane. It is a twostage technique. The membrane represents a foreign body reaction to the spacer applied in the void as the first stage. The second stage includes removal of the spacer and inserting a bone graft. The membrane appears to prevent graft resorption and promote revascularization and consolidation of new bone.

Masquelet [20] reported in 2000 a union rate of $100 \%$ in a series of 35 patients with bone defects ranging from 4 to $25 \mathrm{cms}$. Karger et al., [25] obtained bone union in $90 \%$ of cases in their series. Also, Donegan reported the same percentage of $90 \%$ union in his series of 11 cases. Stafford and Norris [26]reported a union rate of $85 \%$ while Apard et al., [27] in $92 \%$ in a series of 12 patients with segmental bone loss .McCall et al., [28] reported on a series of 20 patients a bony union rate of $85 \%$. On the other hand, Morris in 2017 reported a union rate of only $41 \%$ out of 12 patients with tibial segmental bone defects [24].

As regard the duration to union. Apard et al., [27]reported complete weight-bearing at a mean of 4 months. Donegan et al., [29] reported that ten out of eleven patients with lower extremity segmental bone loss $(90 \%)$ demonstrated radiographic consolidation of the defect an average of 7.5 months after definitive fixation. At six months and 1 year post operative, $70 \%$ and $90 \%$ nonunions were healed respectively in the study done by Stafford and Norris on lower extremity cases. Masquelet et al., in 2000 reported in a series of 35 patients a mean time to full weight bearing of 8.5 months [20].

The most remarkable finding was that there is no relation between the time to union and the size of the defect. However the few number of cases makes it impossible to draw definite conclusions.

Regarding the type of bone fixation, no study has evaluated the optimal bio-mechanical environment for this technique; rather each fracture is "bridged" according to the treating surgeon's as- sessment of the fracture, soft tissue condition and the presence or absence of infection. The degree of stability conferred by the implant must also be considered: Very rigid fixation risks stress shielding which may reduce bone graft integration [29] Conversely, excessive micromotion may result in a weak and poorly vascularized pseudomembrane, which is potentially detrimental [30]. In the originally described technique by Masquelet [20], the fracture site is stabilized by an external fixator. Different means of fracture fixation have been used in the present study and in other studies with success $[24,25,27]$.

As regard to timing of the second stage in this study, the mean interval between the first and second stages was 48 days ( 35 to 62 ) which is comparable to most of the studies $[\mathbf{2 2 , 2 4 , 2 6 , 2 9 ]}$ Traditionally, the interval between the first and second stages has been six to eight weeks [22]. But, A recent study has shown that one-month-old membrane has higher osteogenesis-improving capabilities compared to two-month-old membrane [31].

The technique as described by Masquelet and Begue 32 relied on the placement of morselized cancellous autograft harvested from the iliac crests. If this amount is not sufficient, demineralized allograft is added to the autograft in a ratio that does not exceed 1:3 [32]. The graft can be augmented with growth factors, allograft or other bone substitutes depending on the local requirements [22]. In this series, autograft harvested from the iliac crest was used mainly. Tricalcium phosphate granules were added to the autograft in 6 cases in a ratio of 1:3. Cancellous allograft was used in one case.

The Reamer Irrigator Aspirator or (RIA) system permits the collection of large volumes of bone graft from the medullary canal of the femur. It has been shown to contain higher levels of key growth factors and osteogenic elements than iliac crest graft $[26,33,34]$

Infection remains the primary complication associated with this treatment method $[27,35]$. The quality of the initial debridement of an open fracture is a key factor influencing infection, and hence of the outcome of the technique itself. It is recommended that it should be done by a senior surgeon. Also, the assistance of a competent bacteriologist and consultation of infectious diseases specialist cannot be over emphasized to eradicate infection.

Reported rates of septic complications leading to reconstruction failure range from zero to $8 \%$; 
most of these failures are attributed to inadequate debridement [5,26-28]. Apard et al., [27] reported five septic complications occurred after the second step, reconstruction failure occurred in one of them. Donegan et al., [29] reported one nonunion and one infection in their series of 11 cases both of which occurred in the same patient. However, Morris et al., in 2017, [24] reported five out of 12 (40\%) patients with infective complications. In this series, Infection occurred in two patients (10\%). Reconstruction failure with non-union occurred in both of them. In addition another third case was excluded from the study due to persistence of infection despite of multiple debridements and did not proceed to the second stage. It was noted intraoperatively that the membrane was not well formed.

The use of antibiotics in the cement spacer remains a matter of debate. Apard et al., [27] suggested that they may mask the effect of an inadequate debridement by suppressing but not eradicating any resultant infection. Masquelet et al., [20] recommend using a spacer without antibiotics and a week-long regimen of oral antibiotics to avoid the masking effect. This treatment protocol has the advantage of revealing infection early rather than after the second stage of the procedure, thus avoiding bone graft loss. Conversely use of antibiotic-impregnated cement is well established in the orthopaedic literature; this technique, in combination with adequate debridement has the potential to decrease infection rates in the time between stages of this procedure [36].

In spite of the fact that the technique has the advantage of being simple and does not need a specialized area of expertise, technical execution must be carefully performed. However, complex soft tissue coverage procedures are needed sometimes. The availability of an orthoplastic team is also important for planning of soft tissue coverage as early as possible.

\section{Conclusion:}

Induced membrane technique represents a reliable option in treating post-traumatic segmental bone loss. It is considered an established bone reconstruction procedure for the management of such complex problem.

The concept of induced membrane provides a wide experimental field that needs to be explored. Further studies are needed to evaluate osteoinductive factors and timing of their release in order to determine the optimal timing of the second stage. Another questionable issue is the optimal chemical composition of the spacer. Also, the type of graft material used to fill the void needs further investigation to determine which will give the best clinical and radiological outcomes.

\section{References}

1- LASANIANOS N.G., KANAKARIS N.K. and GIANNOUDIS P.V.: Current management of long bone large segmental defects. Orthop. Trauma., 24 (2): 149-163, 2010.

2- GUGALA Z., LINDSEY R.W. and GOGOLEWSKI S.: New approaches in the treatment of critical-size segmental defects in long bones. In: Macromolecular Symposia, Vol. 253: 147-161, 2007.

3- KEATING JF.: The management of fractures with bone loss. J. Bone. Jt. Surg. Br., Vol. 87-B (2): 142-150. 2005.

4- MASQUELET A.: Muscle reconstruction in reconstructive surgery: Soft tissue repair and long bone reconstruction. Langenbeck's Arch. Surg., 388 (5): 344-346, 2003.

5- LIN C.H., WEI F.C., CHEN H.C. and CHUANG D.C.: Outcome comparison in traumatic lower-extremity reconstruction by using various composite vascularized bone transplantation. Plast. Reconstr. Surg., 104 (4): 984-992, 1999.

6- HAN C.S., WOOD M.B., BISHOP A.T. andCOONEY W.P.: Vascularized bone transfer. J. Bone. Joint. Surg. Am., 74 (10): 1441-1449, 1992.

7- MAY J.W., JUPITER J.B., WEILAND A.J. and BYRD H.S.: Clinical classification of post-traumatic tibial osteomyelitis. J. Bone. Joint. Surg. Am., 71 (9): 1422-1428, 1989.

8- PAPAKOSTIDIS C., BHANDARI M. and GIANNOUDIS P.V.: Distraction osteogenesis in the treatment of long bone defects of the lower limbs: Effectiveness, complications and clinical results; a systematic review and metaanalysis. Bone. Joint. J., 95-B (12): 1673-1680, 2013.

9- EL-ALFY B., EL-MOWAFI H. and EL-MOGHAZY N.: Distraction osteogenesis in management of composite bone and soft tissue defects. Int. Orthop., 34 (1): 115118,2010

10- EL-ROSASY M.A.: Acute shortening and re-lengthening in the management of bone and soft-tissue loss in complicated fractures of the tibia. J. Bone. Joint. Surg. Br., 89 (1): 80-88, 2007.

11- MAINI L., CHADHA M., VISHWANATH J., KAPOOR S., MEHTANI A. and DHAON B.K.: The Ilizarov method in infected nonunion of fractures. Injury, 31 (7): 509-517, 2000.

12- POLYZOIS D., PAPACHRISTOU G., KOTSIOPOULOS $\mathrm{K}$. and PLESSAS S.: Treatment of tibial and femoral bone loss by distraction osteogenesis. Experience in 28 infected and 14 clean cases. Acta. Orthop. Scand. Suppl., 275: 8488, 1997.

13- GIOTAKIS N., NARAYAN B. and NAYAGAM S.: Distraction osteogenesis and nonunion of the docking site: Is there an ideal treatment option? Injury, 38 (1): S 100-S107, 2007.

14- MALIZOS K.N., ZALAVRAS C.G., SOUCACOS P.N., BERIS A.E. and URBANIAK J.R.: Free vascularized 
fibular grafts for reconstruction of skeletal defects. J. Am Acad. Orthop. Surg., 12 (5): 360-369, 2004.

15- YAJIMA H., TAMAI S., MIZUMOTO S. and ONO H.: Vascularised fibular grafts for reconstruction of the femur. J. Bone. Joint. Surg. Br., 75 (1): 123-128, 1993.

16- MINAMI A., KASASHIMA T., IWASAKI N., KATO H. and KANEDA K.: Vascularised fibular grafts. An experience of 102 patients. J. Bone. Joint. Surg. Br., 82 (7): 1022-1025, 2000

17- MOLINA C.S., STINNER D.J. and OBREMSKEY W.T.: Treatment of Traumatic Segmental Long-Bone Defects: A Critical Analysis Review. JBJS Rev., 2 (4): e1-e1, 2014.

18- TABRIZI M.: Distraction Osteogenesis and Its Challenges in Bone Regeneration. In: Bone Regeneration. In Tech., 2012.

19- HERZENBERG J.E, SCHEUFELE L.L., PALEY D. and BECHTEL R., TEPPER S.: Knee range of motion in isolated femoral lengthening. Clin. Orthop. Relat. Res., (301): 49-54, 1994.

20- MASQUELET A.C., FITOUSSI F., BEGUE T. and MULLER G.P.: Reconstruction of the long bones by the induced membrane and spongy autograft. Ann. Chir. Plast. Esthet., 45 (3): 346-353, 2000.

21- MASQUELET A.C. and BEGUE T.: The Concept of Induced Membrane for Reconstruction of Long Bone Defects. Orthop. Clin. North. Am., 41 (1): 27-37, 2010.

22- GIANNOUDIS P V., FAOUR O, GOFF T, KANAKARIS N, DIMITRIOU R.: Masquelet technique for the treatment of bone defects: Tips-tricks and future directions. Injury., 42 (6): 591-598, 2011.

23- PELISSIER P., MASQUELET A.C., BAREILLE R., MATHOULIN PELISSIER S. and AMEDEE J.: Induced membranes secrete growth factors including vascular and osteoinductive factors and could stimulate bone regeneration. J. Orthop. Res., 22 (1): 73-79, 2004.

24- MORRIS R., HOSSAIN M., EVANS A. and PALLISTER I.: Induced membrane technique for treating tibial defects gives mixed results. Bone. Joint J., 99-B (5): 680-685, 2017.

25- KARGER C., KISHI T., SCHNEIDER L., FITOUSSI F. and MASQUELET AC.: Treatment of posttraumatic bone defects by the induced membrane technique. Orthop Traumatol. Surg. Res., 98 (1): 97-102, 2012.

26- STAFFORD P.R. and NORRIS B.L.: Reamer-irrigatoraspirator bone graft and bi Masquelet technique for segmental bone defect nonunions: A review of 25 cases. Injury, 41, 2010.

27- APARD T., BIGORRE N., CRONIER P., DUTEILLE F., BIZOT P. and MASSIN P.: Two-stage reconstruction of post-traumatic segmental tibia bone loss with nailing. Orthop. Traumatol. Surg. Res. 96 (5): 549-553, 2010.

28- McCALL T.A., BROKAW D.S., JELEN B.A., et al.: Treatment of Large Segmental Bone Defects with ReamerIrrigator-Aspirator Bone Graft: Technique and Case Series. Orthop. Clin. North. Am., 41 (1): 63-73, 2010.

29- DONEGAN D.J., SCOLARO J., MATUSZEWSKI P.E., MEHTA S.: Staged Bone Grafting Following Placement of an Antibiotic Spacer Block for the Management of Segmental Long Bone Defects. Orthopedics, 34 (11): e730-e735, 2011.

30- AURÉGAN J.C. and BÉGUÉ T.: Induced membrane for treatment of critical sized bone defect: A review of experimental and clinical experiences. Int. Orthop., 38 (9): 1971-1978, 2014

31- AHO O-M., LEHENKARI P., RISTINIEMI J., LEHTONEN S., RISTELI J. and LESKELÄ H-V.: The Mechanism of Action of Induced Membranes in Bone Repair. J. Bone. Jt. Surg., 95 (7): 597-604, 2013.

32- MASQUELET A.C. and BEGUE T.: The Concept of Induced Membrane for Reconstruction of Long Bone Defects. Orthop. Clin. North. Am., 41 (1): 27-37, 2010.

33- SCHMIDMAIER G., HERRMANN S., GREEN J., et al.: Quantitative assessment of growth factors in reaming aspirate, iliac crest, and platelet preparation. Bone, 39 (5): 1156-1163, 2006.

34- WILDEMANN B., KADOW-ROMACKER A., HAAS N.P. and SCHMIDMAIER G.: Quantification of various growth factors in different demineralized bone matrix preparations. J. Biomed. Mater. Res. Part A, 81 (2): 437 442, 2007.

35- TAYLOR B.C., FRENCH B.G., FOWLER T.T., RUSSELL J. and POKA A.: Induced Membrane Technique for Reconstruction To Manage. Bone. Loss. J. Am. Acad. Orthop. Surg., 20: 142-150, 2012.

36- SANCINETO C.F. and BARLA J.D.: Treatment of long bone osteomyelitis with a mechanically stable intramedullar antibiotic dispenser: Nineteen consecutive cases with a minimum of 12 months follow-up. J. Trauma., 65 (6): 1416-1420, 2008. 


\section{طريقة الغشاء المُحدث (ماسكوليه العزيه لعلاج فقدان جزيء من العظام الطويلة}

يعتبر فقدان جزء من العظام الطويلة نتيجة للاصعابات والحوادث من اصعب المشاكل التى تقاجه جراحى العظام بالعالم. يعتبراستخدام

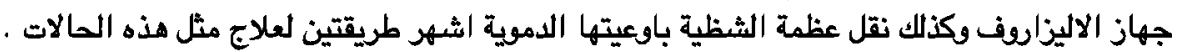

فى عام 1919، ابتكر العالم الفرنسى ماسكوليه طريقة جديدة لحل هذه المشكلة حيث تتكن من مرحلتين. تتضمن المرحلة الاولى وضسع

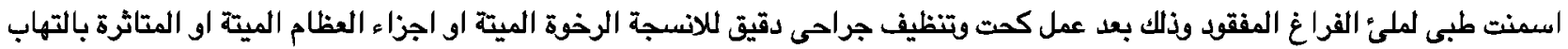

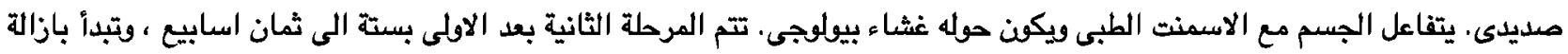

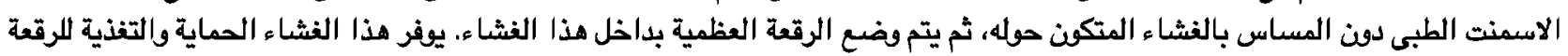
العظمية كما ان له قدرة على تكوين عظام جديد.

تمت هذه الدراسة على عشرين مريض يعانقن من فقدان جزء من العظام الطويلة نتيجة الاصعابات. تراوح طول الجزء المفقول من العظام بين ع الى 19 سم. خضع جميع المرضى لعملية ماسكوليه وتم متابعة المرضى لفترة تتراوح بين ستة اشهر حتى سنى سنة .تم لحام العظام المكسودة في Vالة بنسبة (1V) (1). تعتبر طريقة ماسكوليه في علاج فقدان اجزاء العظام الطويلة الناتج عن الاصابات هى طريقة فعالة وينصع باستخدامها. 